\title{
TRANSFORMATION OF AGRICULTURAL LAND DISTRIBUTION PATTERNS IN RUSSIA
}

\author{
Vasilii Erokhin ${ }^{1}$, Tianming Gao $^{2}$, Jean Vasile Andrei ${ }^{3}$, Anna Ivolga ${ }^{4}$ \\ *Corresponding authorE-mail: basilic@list.ru
}

\begin{abstract}
A R T I C L E I N F O
Original Article

Received: 06 July 2020

Accepted: 15 August 2020

doi: 10.5937/ekoPolj2003863E
\end{abstract}

UDC 316.422:347.453.1(470)

\section{Keywords:}

agriculture, arable land, farming system, land category, land fund, Russia

JEL: Q15, Q24, R14

\section{A B S T R A C T}

In the conditions of degrading resources of fertile arable land, pressing demand for food from a growing world population, and progressing urbanization and industrialization, agricultural land distribution patterns are becoming more vulnerable to a variety of socioeconomic, environmental, and food security challenges. In the context of this trilemma, there is a need to understand the extent to which farming systems will be able to cope with increasing competition for land with other uses. In this study, the authors developed an approach for predicting the likely influences of non-agricultural lands on agricultural landscapes. In the case of diverse agricultural landscapes in Russia, farming systems were mapped based on a share of agricultural land categories in the land fund across 82 administrative entities. The establishment of a rating system and application of correlation analysis allowed revealing the mismatches between the cadasterbased spatial distribution of farming systems and actual inter-category relationships. The proposed framework is applicable internationally for the study of land-use patterns and simulation of agricultural land distribution systems under the influence of non-agricultural land uses.

(C) 2020 EA. All rights reserved.

1 Vasilii Erokhin, Ph.D., Associate Professor, School of Economics and Management, Harbin Engineering University, 145, Nantong Street, Harbin, 150001, China, Phone: +861 56367 09 072, E-mail: basilic@list.ru, ORCID ID (https://orcid.org/0000-0002-3745-5469)

2 Tianming Gao, Ph.D., Associate Professor, School of Economics and Management, Harbin Engineering University, 145, Nantong Street, Harbin, 150001, China, Phone: +861 56367 09 072, E-mail: gaotianming@hrbeu.edu.cn, ORCID ID (https://orcid.org/0000-00025202-8684)

3 Jean Vasile Andrei, Ph.D., Full Professor, Petroleum-Gas University of Ploiesti, 39, B-dul Bucuresti, Ploiesti, 100680, Romania, Phone: +407 27615 540,E-mail: andrei_jeanvasile@ yahoo.com, ORCID ID (https://orcid.org/0000-0002-8332-6537)

4 Anna Ivolga, Ph.D., Associate Professor, Stavropol State Agrarian University, 12, Zootekhnichesky Pereulok, Savropol, 355017, Russia, Phone: +792 80053 542, E-mail: annya_iv@mail.ru, ORCID ID (https://orcid.org/0000-0001-5428-609X) 


\section{Introduction}

While a higher share of agricultural lands in a land fund usually leads to the agricultural development of a territory, higher crop yields, technological innovations in farming, and better livelihood opportunities for rural people (Erokhin, 2018), it may also aggravate depletion of natural resources and misappropriation of the land fund (Yerseitova et al., 2018). Automatically, a higher share of agricultural lands brings neither higher performance to farming systems nor a better configuration of land categories within a land fund for agricultural production. The spatial patterns of farming systems are not static over time due to geophysical, climatic, and environmental processes and well as human interventions that alter land properties (Diogo, 2018). Often, governments, farmers, and other shareholders respond to land distribution patterns pictured by land cadaster, making decisions in the absence of accurate information on the efficiency of spatial allocation of agricultural land and interrelations between various categories of land within a land fund (Cocklin et al., 1987). In case land distribution and correlation tendencies are misinterpreted, the costs of government interventions and stakeholders' activities may be very high.

The causality between land-use change processes and socioeconomic factors has not been adequately explained. Margules and Pressey (2000) developed the spatial framework to identify and classify ecologically significant geographical units capable of reflecting the interaction of various environmental components for the effective use of agricultural land. Irwin and Geoghegan (2001) and Benke et al. (2011) established the models to determine the optimal configuration of land categories for different objectives by applying mathematical optimization techniques. Novkovic et al. (2010) defined a quantitative model for the determination of the size and quality of agricultural land optimal for the utilization in agricultural production. Koomen et al. (2015) investigated the applicability of land-use models to the understanding of correlations between economic development, land accessibility, spatial planning, and local biophysical conditions to be able to forecast the possible future state of the land system. Most of the constructed models, however, apply to only one set of criteria variables (most commonly, a share of agricultural land in a land fund) without further testing for alternative territorial specifications of land use patterns (Diogo, 2018). Furthermore, the influence of non-agricultural land on farming systems has remained underinvestigated. Instead of exploring the correlations between the categories of agricultural, urban, infrastructure, and industrial land, agricultural landscapes have commonly been considered out of non-agricultural context (Stacherzak, 2019). This deepens the problem of proper understanding of agriculture-to-urban land transition and land loss in agriculture due to the pressure from other land categories.

Therefore, there is a knowledge gap concerning agricultural landscapes in terms of how the interactions between various land categories and land-use types may be influenced to optimize the allocation of fertile and productive agricultural lands for better performance of farming systems. For instance, in Russia, the distribution of agricultural land is very fragmented. Agricultural lands only represent $12.96 \%$ of the total national 
land fund (cropland at $7.16 \%$, rangeland at $3.99 \%$, hayfields at $1.40 \%$, fallow at $0.28 \%$, and perennial plantings at $0.11 \%$ ) (Erokhin et al., 2020). As agricultural land systems are facing a complex food-economy-environment trilemma in the context of increasing competition for land (Verburg et al., 2013), there is a need to understand better the determinants of such patterns and their behavior in terms of inter-category relationships within a land fund. A more explicit focus upon the optimization of land fund structure at a regional scale is required to be able to identify major land-related processes that determine land system dynamics and agroecosystem productivity in particular locations (Moss, 1985). With this background, this study aims to reveal how land categories interact within a land fund in diverse agricultural landscapes and how differentiation of interplays between agricultural, urban, industrial, and other types of land can contribute to the understanding of agricultural land systems and their determinants.

\section{Materials and methods}

For the purpose of this study, the authors modified the methodology framework previously employed by Erokhin et al. (2020) for revealing inter-category correlations within a land fund at regional scales across Russia. The array included five categories of agricultural land (arable land $\left(L_{1}\right)$, fallows $\left(L_{2}\right)$, perennial plantings $\left(L_{3}\right)$, hayfields $\left(L_{4}\right)$, and rangelands $\left.\left(L_{5}\right)\right)$ and nine categories of non-agricultural land (woodlands $\left(L_{6}\right)$, forest ranges $\left(L_{7}\right)$, water reserve lands $\left(L_{8}\right)$, residential and industrial lands $\left(L_{9}\right)$, lands under transportation and communication infrastructure $\left(L_{10}\right)$, wetlands $\left(L_{11}\right)$, disturbed lands $\left(L_{12}\right)$, barren $\left(L_{13}\right)$, and other not specified lands $\left(L_{14}\right)$.

The selection of land categories was based on the reports of the Federal Service for State Registration, Cadastre, and Cartography (Rosreestr) and the Federal State Statistics Service of the Russian Federation (Rosstat). According to Russia's cadaster system, these categories are mutually exclusive and exhaustive, each location within the administrative entity is classified into one and only one land category.

As the study aims to reveal how the acreage of agricultural land is affected by other land categories in various land distribution patterns, an assessment scale was applied. To establish a relevant ranking framework, it is critical to align categorization of land funds (land cadaster data) with functional scales. In agriculture, correlations between lands are hardly identified as categorical data and thus can not be effectively linked with the fragmentation of agricultural production across territories. In this study, land cadaster structure was ranked based on the parameter of land activity, i.e. the contribution of a land category to the total land acreage per territory (Equation 1).

$$
A_{j L i}=\frac{S_{j L i}}{S_{j}}
$$

where $A_{j L i}$ is the activity of land category $L_{i}$ in territory $T_{j} ; S_{j L i}$ is the area of $L_{i}$ in territory $T_{j} ; S_{j}$ is total land acreage of territory $T_{j}$. 
To exclude bias factors' effects and make the approach applicable internationally, this study proposed a scale differentiating the values of $R_{j}$ in terms of the degree of land activity. Simple averaging of the highest $\left(R_{\text {jmax }}\right)$ and the lowest $\left(R_{\text {jmin }}\right)$ ranks resulted in the average value $\left(R_{\text {javer }}\right)$. The upper and the lower limits of $R_{\text {javer }}$ were derived by simple averaging of $R_{\text {jmax }}$ and $R_{\text {javer }}$ and $R_{\text {jmin }}$ and $R_{\text {javer }}$, respectively. The type of agricultural land activity in a territory was identified by falling of $R_{j}$ into one of the categories: high, above average, below average, and low (Table 1).

Table 1. Scale to measure the degree of agricultural land activity

\begin{tabular}{|l|l|}
\hline \multicolumn{1}{|c|}{ Type of activity } & Scale \\
\hline Type I: high & $\frac{R_{\text {jmax }}+R_{\text {javer }}}{2} \leq R_{j} \leq R_{\text {jmax }}$ \\
\hline Type II: above average & $\frac{R_{\text {jmax }}+R_{\text {javer }}}{2}>R_{j} \geq R_{\text {javer }}$ \\
\hline Type III: below average & $\frac{R_{\text {javer }}>R_{j} \geq \frac{R_{\text {jmin }}+R_{\text {javer }}}{2}}{2}$ \\
\hline Type IV: low & $\frac{R_{\text {jmin }}+R_{\text {javer }}}{2}>R_{j} \geq R_{\text {jmin }}$ \\
\hline
\end{tabular}

Source: Authors' development

Land distribution patterns are continuously changing in response to affecting natural, climate, anthropogenic, and socioeconomic factors and consequent variations in land cadaster structure. To understand the correlations between, first, the four types of land activity and, second, land categories within each type, this study employed factor analysis. Since the synergies between land categories are represented as changes from one type of land activity to other, correlation analysis is deemed appropriate to reveal how land structure adjustments affect the activity of land categories $L_{1-5}$. Correlation matrixes were built separately for the four groups of territories earlier ranked by the type of agricultural land activity. The idea is to reveal which land structure adjustments affect categories of agricultural land in different types of land activity patterns.

When conducting a correlation analysis for land systems, most scholars faced a challenge of how to find an appropriate measure to decide on the significance of synergies between the factors (land categories). Werts et al. (1976), Omar et al. (2015), and Sangngam (2014) tested various solutions, among which the coefficient of correlation variance seemed to be the most appropriate for dealing with interdependent multitudes of land categories across a variety of territorial land systems and land activity types (Equation 2).

$$
C_{c v}=\frac{\sum R_{j i}}{R_{\max } \times L \times T}
$$

where $C_{c v}$ is the coefficient of correlation variance; $\sum R_{j i}$ is the sum of $R_{i}$ ranks of $T_{j}$ territories included in the group; $R_{\max }$ is the highest possible rank of $T_{j}$ on $A_{L i}\left(R_{\max }=\right.$ $81) ; L$ is the number of land categories included in the array $(L=14) ; T$ is the number of territories included in the array. 
The study was performed based on land cadaster data derived from 82 administrative entities of Russia grouped in eight districts (Table 2). The municipal areas of Moscow, Saint-Petersburg, and Sevastopol were excluded from the array as those in which agricultural land's portion of total land funds was of negligible importance. The consideration of the Crimea Republic as a part of the array was determined by the position of the territory as being de-facto controlled by Russia. These results do not reflect the authors' attitude to the international status of the area.

Table 2. Administrative entities included in the study

\begin{tabular}{|l|c|l|}
\hline $\begin{array}{c}\text { Federal } \\
\text { district }\end{array}$ & $\begin{array}{c}\text { Number of } \\
\text { territories }\end{array}$ & \multicolumn{1}{c|}{ Administrative entities } \\
\hline Central & 17 & $\begin{array}{l}\text { Belgorod, Bryansk, Vladimir, Voronezh, Ivanovo, Kaluga, Kostroma, } \\
\text { Kursk, Lipetsk, Moscow (oblast), Orel, Ryazan, Smolensk, Tambov, Tver, } \\
\text { Tula, Yaroslavl }\end{array}$ \\
\hline Northwest & 10 & $\begin{array}{l}\text { Karelia, Komi, Arkhangelsk, Vologda, Kaliningrad, Leningrad, Murmansk, } \\
\text { Novgorod, Pskov, Nenets }\end{array}$ \\
\hline South & 7 & Adygeya, Kalmykia, Crimea, Krasnodar, Astrakhan, Volgograd, Rostov \\
\hline $\begin{array}{l}\text { North } \\
\text { Caucasus }\end{array}$ & 7 & $\begin{array}{l}\text { Dagestan, Ingushetia, Kabardino-Balkaria, Karachaevo-Cherkessia, North } \\
\text { Osetia Alania, Chechnya, Stavropol }\end{array}$ \\
\hline Volga & 14 & $\begin{array}{l}\text { Bashkortostan, Mari El, Mordovia, Tatarstan, Udmurtia, Chuvashia, Perm, } \\
\text { Kirov, Nizhny Novgorod, Orenburg, Penza, Samara, Saratov, Ulyanovsk }\end{array}$ \\
\hline Ural & 6 & Kurgan, Sverdlovsk, Tyumen, Chelyabinsk, Khanty-Mansi, Yamal-Nenets \\
\hline Siberia & 12 & $\begin{array}{l}\text { Altay Republic, Buryatia, Tyva, Khakasia, Altay, Zabaikalsk, Krasnoyarsk, } \\
\text { Irkutsk, Kemerovo, Novosibirsk, Omsk, Tomsk }\end{array}$ \\
\hline Far East & 9 & $\begin{array}{l}\text { Yakutia, Kamchatka, Primorye, Khabarovsk, Amur, Magadan, Sakhalin, } \\
\text { Jewish AO, Chukotka }\end{array}$ \\
\hline
\end{tabular}

Source: Authors' development

Cadaster data were obtained from the Federal Service for State Registration, Cadastre and Cartography of the Russian Federation (2020) and the Federal State Statistics Service of the Russian Federation $(2016,2020)$. The data for 81 territories were generalized from 2010 through 2018, while those for the Crimea Republic were averaged since 2015.

\section{Results}

The ranking of Russia's territories on a parameter of agricultural land activity rather predictably resulted in the higher scores for the southern and central parts of the country than for Siberia and the Far East. Concurrently, however, some less apparent findings were yielded.

First, the territories that comprise the South Federal District, an agricultural granary of the country, demonstrated weaker orientation of land fund structure toward agricultural specialization compared to the Central and Volga districts and some regions of Siberia. Specifically, for Krasnodar and Rostov, the territories with a considerable portion of arable land in the structure of the land fund, $R$ values were well below the district average. In some arable farming regions of the Russian South and Center, high $L_{1}$ and $L_{5}$ grades were negated by low $L_{8-10}$ and $L_{12}$ scores. 
Second, the aggregated ranking of the Siberia Federal District surpassed the level of land activity of the Northwest and Ural districts and nearly reached that of the South district. In Omsk and Novosibirsk, the above-average $R$ values were due to high $L_{4}$ and $L_{12-14}$. The Altay was rated high for the contribution of arable land, fallow, hayfields, and rangeland to the land fund, as well as for the low portion of disturbed land.

Third, the Far East is the least agriculture-oriented macroregion in Russia with the national lowest ranks of agricultural land activity and the highest spatial constraints for the allocation of the agricultural land uses. In Chukotka, Magadan, and Sakhalin, where land funds are predominantly comprised of woodlands and wetlands, the $L_{l-5}$ scores were the lowest among 82 territories included in the study. Nevertheless, in the southern part of the macroregion, some agricultural land categories were ranked higher than those in Russia's South and Center $\left(L_{2}\right.$ in Primorye, Khabarovsk, and Amur and $L_{4}$ and $L_{5}$ in Jewish AO).

Following from the obtained ranks, four $R_{j}$ intervals were identified each of which included $T_{j}$ territories according to the degrees of agricultural land activity (Table 3 ).

Table 3. Types of $T_{j}$ territories on agricultural land activity scores

\begin{tabular}{|c|c|c|c|c|c|}
\hline $\begin{array}{l}\text { Type of } \\
\text { activity }\end{array}$ & $\underset{\text { intervals }}{\mathbf{R}_{\mathrm{j}}}$ & $\sum \mathbf{R}_{\mathrm{ji}}$ & $\mathbf{T}$ & $T_{j}$ territories and their $R_{j}$ scores & $\mathrm{C}_{\mathrm{cv}}$ \\
\hline $\begin{array}{l}\text { Type I: } \\
\text { high }\end{array}$ & $661-770$ & 8,502 & 12 & $\begin{array}{l}\text { Orel (770), Kurgan (765), Penza (744), Omsk } \\
\text { (731), Ingushetia (700), Tula (698), Kaluga (693), } \\
\text { Altay (689), Mordovia (682), Orenburg (681), } \\
\text { Tambov (677), Novosibirsk (672) }\end{array}$ & 0.6251 \\
\hline $\begin{array}{l}\text { Type II: } \\
\text { above } \\
\text { average }\end{array}$ & $553-660$ & 20,130 & 33 & $\begin{array}{l}\text { Ryazan (660), Saratov (659), Karachaevo- } \\
\text { Cherkessia (656), Tyumen (654), Stavropol (644), } \\
\text { Astrakhan (642), Chuvashia (634), Dagestan } \\
\text { (634), Volgograd (632), Voronezh (631), Kursk } \\
\text { (621), Ulyanovsk (618), Samara (617), Lipetsk } \\
\text { (616), Kalmykia (615), Crimea (610), Kabardino- } \\
\text { Balkaria (608), Bryansk (605), Nizhny Novgorod } \\
\text { (605), North Osetia Alania (604), Mari El } \\
\text { (601), Udmurtia (599), Bashkortostan (594), } \\
\text { Chelyabinsk (594), Kirov (591), Smolensk (585), } \\
\text { Tomsk (582), Zabaikalsk (580), Chechnya (579), } \\
\text { Khakasia (577), Pskov (566), Kostroma (561), } \\
\text { Belgorod (556) }\end{array}$ & 0.5379 \\
\hline $\begin{array}{l}\text { Type III: } \\
\text { below } \\
\text { average }\end{array}$ & $401-552$ & 14,476 & 30 & $\begin{array}{l}\text { Perm (550), Altay Republic (549), Rostov (549), } \\
\text { Tatarstan (544), Vladimir (523), Jewish AO } \\
\text { (523), Adygeya (520), Sverdlovsk (513), Moscow } \\
\text { Oblast (509), Ivanovo (506), Tver (501), Tyva } \\
\text { (497), Amur (494), Kemerovo (491), Krasnodar } \\
\text { (489), Vologda (487), Buryatia (481), Kaliningrad } \\
\text { (480), Karelia (462), Primorye (458), Khabarovsk } \\
\text { (457), Irkutsk (455), Yaroslavl (448), Novgorod } \\
\text { (446), Kamchatka (440), Khanty-Mansi (436), } \\
\text { Arkhangelsk (429), Sakha Yakutia (420), } \\
\text { Krasnoyarsk (411), Komi (408) }\end{array}$ & 0.4255 \\
\hline
\end{tabular}




\begin{tabular}{|r|r|r|r|l|c|}
\hline $\begin{array}{r}\text { Type of } \\
\text { activity }\end{array}$ & $\begin{array}{c}\mathbf{R}_{\mathrm{j}} \\
\text { intervals }\end{array}$ & $\sum \mathbf{R}_{\mathrm{ji}}$ & $\mathbf{T}$ & \multicolumn{1}{|c|}{$\mathbf{T}_{\mathbf{j}}$ territories and their $\mathbf{R}_{\mathrm{j}}$ scores } & $\mathbf{C}_{\mathrm{cv}}$ \\
\hline $\begin{array}{l}\text { Type IV: } \\
\text { low }\end{array}$ & $250-400$ & 2,264 & $7 \begin{array}{l}\text { Leningrad (394), Magadan (383), Nenets (327), } \\
\text { Chukotka (323), Sakhalin (320), Murmansk (267), } \\
\text { Yamal-Nenets (250) }\end{array}$ & 0.2852 \\
\hline
\end{tabular}

Source: Authors' development

Based on the categorization of the territories, the per-group coefficients of correlation variance $C_{c v}$ were computed. The checking of the correlation matrixes against $C_{c v}$ allowed to reveal the strongest correlations between $L_{1-5}$ and $L_{6-14}$ land categories for four types of territories.

Type I territories make a modest contribution to Russia's national agricultural output. They are relatively small administrative entities adjacent to big agglomerations of Moscow in the central part of Russia and Novosibirsk in Siberia. In such lowscale semi-urbanized farming systems, the most substantial effect on the activity of agricultural land categories is caused by non-agricultural land under infrastructure, primarily transportation and communication (the strongest correlation with $L_{1}, L_{3}$, and $L_{4}$ ). (Table 4). One of the side effects caused by intensive industrial and infrastructure construction is the extension of barren, which, in turn, affects the acreage of fallow and rangelands. Strong correlations were also revealed between agricultural land categories and wetlands, water fund lands, woodland, and other forest range.

Table 4. Correlation matrix for Type I territories

\begin{tabular}{|c|c|c|c|c|c|c|c|c|c|c|c|c|c|}
\hline \multirow{2}{*}{$\mathbf{Y}$} & \multicolumn{13}{|c|}{$\mathbf{X}$} \\
\hline & $\mathbf{R}_{1}$ & $\mathbf{R}_{2}$ & $\mathbf{R}_{3}$ & $\mathbf{R}_{4}$ & $\mathbf{R}_{5}$ & $\mathbf{R}_{6}$ & $\mathbf{R}_{7}$ & $\mathbf{R}_{8}$ & $\mathbf{R}_{9}$ & $\mathbf{R}_{10}$ & $\mathbf{R}_{11}$ & $\mathbf{R}_{12}$ & $\mathbf{R}_{13}$ \\
\hline $\mathrm{R}_{2}$ & 0.029 & & & & & & & & & & & & \\
\hline $\mathrm{R}_{3}$ & 0.507 & 0.226 & & & & & & & & & & & \\
\hline $\mathrm{R}_{4}$ & 0.547 & 0.085 & $0.714 *$ & & & & & & & & & & \\
\hline $\mathrm{R}_{5}$ & 0.039 & 0.580 & 0.126 & 0.107 & & & & & & & & & \\
\hline $\mathrm{R}_{6}$ & $0.724 *$ & 0.299 & 0.095 & 0.167 & 0.358 & & & & & & & & \\
\hline$R_{7}$ & $0.682 *$ & 0.081 & 0.392 & 0.472 & 0.052 & 0.575 & & & & & & & \\
\hline $\mathrm{R}_{8}$ & 0.523 & 0.362 & $0.744 *$ & \begin{tabular}{|l}
$0.759^{*}$ \\
\end{tabular} & 0.197 & 0.205 & 0.434 & & & & & & \\
\hline $\mathrm{R}_{9}$ & 0.443 & 0.270 & 0.587 & 0.469 & 0.018 & 0.041 & 0.369 & $0.757^{*}$ & & & & & \\
\hline $\mathrm{R}_{10}$ & $0.795^{*}$ & 0.021 & 0.804* & 0.836* & 0.089 & 0.434 & $0.640 *$ & 0.752* & 0.504 & & & & \\
\hline $\mathrm{R}_{\Perp}$ & $0.630^{*}$ & 0.414 & $0.682 *$ & 0.773* & 0.430 & 0.459 & 0.398 & $0.876^{*}$ & $0.650^{*}$ & $0.782 *$ & & & \\
\hline $\mathrm{R}_{12}$ & 0.422 & 0.391 & 0.421 & 0.204 & 0.019 & 0.250 & 0.234 & 0.570 & 0.528 & 0.534 & 0.505 & & \\
\hline $\mathrm{R}_{13}$ & 0.028 & $0.719^{*}$ & 0.083 & 0.028 & 0.765 & 0.186 & 0.020 & 0.300 & 0.276 & 0.133 & 0.411 & 0.059 & \\
\hline $\mathrm{R}_{14}$ & 0.112 & 0.619 & 0.045 & 0.035 & 0.714 & 0.112 & 0.021 & 0.211 & 0.140 & 0.183 & 0.327 & 0.111 & $0.956^{*}$ \\
\hline
\end{tabular}

Note: * strong correlation, $C_{R i}>C_{c v}(0.6251$ for Type I territories $)$

Source: Authors' development

Type II group is the biggest among the four defined in this study. On the one hand, the territories are very diverse. As the Type II belt stretches from the most southern part of the country (Dagestan) to the $58^{\circ}$ north latitude (Pskov) and from the western 
borders of Russia (Bryansk) to the Far East (Zabaikalsk), it covers a great variety of climate zones, landscapes, and types of farming systems. On the other hand, Type II territories bear similarities to each other. Similar to Type I, most of Type II territories are urbanized and industrialized areas, in which arable farming systems (notably, $L_{l}$ and $L_{3}$ land categories) are affected by the spread of infrastructure and communication construction (Table 5).

As the Type II belt concentrates in the western and central parts of Russia, it predominantly comprises densely populated territories (Belgorod, Voronezh, Lipetsk, Kursk, Samara), in which the correlation between arable and residential lands is the highest. In many of Type II territories, the contribution of woodlands and other forest range to the structure of the land fund is essential. As the analysis demonstrated, it reflected in high correlations between $L_{6}$ and rangelands and arable land. In the southern areas of the Type II belt, where climate and soils favor the development of horticulture and viniculture, $C_{c v}$ emphasized a strong correlation between cadaster categories of perennial plantings and arable lands.

Table 5. Correlation matrix for Type II territories

\begin{tabular}{|l|r|r|r|r|r|r|r|r|r|l|l|l|l|}
\hline \multirow{2}{*}{$\mathbf{Y}$} & \multicolumn{9}{|c|}{$\mathbf{X}$} \\
\hline & $\mathbf{R}_{1}$ & $\mathbf{R}_{2}$ & $\mathbf{R}_{3}$ & $\mathbf{R}_{4}$ & $\mathbf{R}_{5}$ & $\mathbf{R}_{6}$ & $\mathbf{R}_{7}$ & $\mathbf{R}_{8}$ & $\mathbf{R}_{9}$ & $\mathbf{R}_{10}$ & $\mathbf{R}_{11}$ & $\mathbf{R}_{12}$ & $\mathbf{R}_{13}$ \\
\hline $\mathrm{R}_{2}$ & 0.190 & & & & & & & & & & & & \\
\hline $\mathrm{R}_{3}$ & $0.702^{*}$ & 0.229 & & & & & & & & & & & \\
\hline $\mathrm{R}_{4}$ & 0.310 & 0.054 & 0.096 & & & & & & & & & & \\
\hline $\mathrm{R}_{5}$ & 0.205 & 0.418 & 0.388 & 0.020 & & & & & & & & & \\
\hline $\mathrm{R}_{6}$ & $0.583^{*}$ & 0.450 & $0.603^{*}$ & 0.165 & $0.753^{*}$ & & & & & & & & \\
\hline $\mathrm{R}_{7}$ & $0.554^{*}$ & 0.078 & 0.451 & 0.065 & 0.159 & 0.154 & & & & & & & \\
\hline $\mathrm{R}_{8}$ & 0.031 & 0.216 & 0.042 & 0.327 & 0.140 & 0.267 & 0.324 & & & & & & \\
\hline $\mathrm{R}_{9}$ & $0.866^{*}$ & 0.158 & $0.837 *$ & 0.158 & 0.337 & 0.526 & 0.456 & 0.069 & & & & & \\
\hline $\mathrm{R}_{10}$ & $0.765^{*}$ & 0.020 & $0.718^{*}$ & 0.053 & 0.017 & 0.283 & $0.580^{*}$ & 0.159 & $0.644^{*}$ & & & & \\
\hline $\mathrm{R}_{11}$ & 0.454 & 0.374 & $0.565^{*}$ & 0.225 & $0.608^{*}$ & 0.408 & 0.061 & 0.036 & $0.556^{*}$ & 0.394 & & & \\
\hline $\mathrm{R}_{12}$ & 0.200 & 0.094 & 0.152 & 0.299 & 0.143 & 0.199 & 0.511 & 0.458 & 0.151 & 0.331 & 0.042 & & \\
\hline $\mathrm{R}_{13}$ & 0.114 & 0.327 & 0.124 & 0.247 & $0.697 *$ & 0.334 & 0.276 & 0.242 & 0.126 & 0.221 & 0.479 & 0.147 & \\
\hline $\mathrm{R}_{14}$ & 0.004 & 0.347 & 0.290 & 0.044 & 0.480 & $0.564 *$ & 0.337 & 0.106 & 0.253 & 0.176 & $0.599^{*}$ & 0.270 & $0.806^{*}$ \\
\hline
\end{tabular}

Note: * strong correlation, $C_{R i}>C_{c v}(0.5379$ for Type II territories $)$

Source: Authors' development

The Type III belt includes three locuses of territories. The eastern one, Siberia and the Far East, occupies over half of the territory of Russia but concentrates only $12.3 \%$ of its agricultural land. Among the categories of agricultural land, rangelands prevail in the structure of land fund in all territories of the eastern locus except its most southern parts (Krasnoyarsk, Irkutsk, Kemerovo, Primorye, and Amur). The acreage of rangelands strongly correlates with that of woodlands, other forest range, and wetlands (Table 6). 
Table 6. Correlation matrix for Type III territories

\begin{tabular}{|c|c|c|c|c|c|c|c|c|c|c|c|c|c|}
\hline \multirow{2}{*}{$\mathbf{Y}$} & \multicolumn{13}{|c|}{$X$} \\
\hline & $\mathbf{R}_{1}$ & $\mathbf{R}_{2}$ & $\mathbf{R}_{3}$ & $\mathbf{R}_{4}$ & $\mathbf{R}_{5}$ & $\mathbf{R}_{6}$ & $\mathbf{R}_{7}$ & $\mathbf{R}_{8}$ & $\mathbf{R}_{9}$ & $\mathbf{R}_{10}$ & $\mathbf{R}_{11}$ & $\mathbf{R}_{12}$ & $\mathbf{R}_{13}$ \\
\hline $\mathrm{R}_{2}$ & 0.060 & & & & & & & & & & & & \\
\hline $\mathrm{R}_{3}$ & $0.502 *$ & 0.036 & & & & & & & & & & & \\
\hline $\mathrm{R}_{4}$ & 0.425 & 0.329 & $0.549 *$ & & & & & & & & & & \\
\hline $\mathrm{R}_{5}$ & 0.423 & 0.051 & 0.418 & 0.273 & & & & & & & & & \\
\hline $\mathrm{R}_{6}$ & $0.729 *$ & 0.311 & $0.625^{*}$ & 0.117 & $0.711 *$ & & & & & & & & \\
\hline $\mathrm{R}_{7}$ & 0.394 & 0.376 & 0.338 & \begin{tabular}{|l}
$0.477 *$ \\
\end{tabular} & $0.628 *$ & 0.361 & & & & & & & \\
\hline $\mathrm{R}_{8}$ & 0.260 & 0.370 & 0.237 & 0.177 & 0.039 & 0.311 & 0.211 & & & & & & \\
\hline $\mathrm{R}_{9}$ & $0.610^{*}$ & 0.038 & $0.568 *$ & 0.406 & 0.405 & $0.624 *$ & 0.368 & 0.252 & & & & & \\
\hline $\mathrm{R}_{10}$ & $0.602 *$ & 0.020 & \begin{tabular}{|l|l|}
$0.468 *$ \\
\end{tabular} & 0.351 & $0.483 *$ & $0.595^{*}$ & 0.388 & 0.197 & $0.966^{*}$ & & & & \\
\hline $\mathrm{R}_{11}$ & 0.354 & 0.175 & 0.413 & 0.196 & $0.649 *$ & 0.478 & 0.241 & 0.007 & $0.578^{*}$ & $0.576^{*}$ & & & \\
\hline $\mathrm{R}_{12}$ & 0.300 & 0.148 & \begin{tabular}{|l|l|}
$0.624 *$ \\
\end{tabular} & 0.816* & 0.170 & 0.137 & 0.404 & 0.077 & 0.381 & $0.725^{*}$ & 0.120 & & \\
\hline $\mathrm{R}_{13}$ & $0.909 *$ & 0.069 & $0.550 *$ & 0.405 & 0.079 & 0.156 & 0.343 & 0.385 & $0.584 *$ & $0.599 *$ & 0.037 & \begin{tabular}{|l|l|}
$0.720 *$ \\
\end{tabular} & \\
\hline $\mathrm{R}_{14}$ & 0.232 & 0.175 & 0.249 & 0.418 & 0.129 & $0.112^{*}$ & \begin{tabular}{ll|}
0.190 \\
\end{tabular} & \begin{tabular}{ll|}
0.291 \\
\end{tabular} & 0.326 & 0.354 & 0.169 & $0.727 *$ & $0.832^{*}$ \\
\hline
\end{tabular}

Note: * strong correlation, $C_{R i}>C_{c v}(0.4255$ for Type III territories $)$

Source: Authors' development

Second locus, the northern one, includes the territories of Russia's Northwest, Ural, and Center (north of Moscow). In these territories, the contribution of arable lands to the structure of the land fund is considerably more substantial compared to that in the eastern locus. Similar to Type I and Type II territories, northern areas are highly industrialized but less populated. Commonly, extensive industrial development and exploration of underpopulated regions tend to trigger the emergence of disturbed land focals and degradation of agricultural lands. The analysis revealed strong relationships between $L_{12}$ and $L_{3}$, as well as between $L_{13}$ and $L_{1}$. The southern locus is the smallest among the three, but the one to be recognized as a breadbasket of the country. It includes the territories in which arable land dominates in the structure of the land fund (58.5\% in Rostov and 52.8\% in Krasnodar). At the same time, due to one of Russia's highest rates of population density and resort and transport infrastructure concentration in Krasnodar, Rostov, and Adygeya, the study demonstrated the correlations between the acreage of arable land $L_{1}$ and perennial plantings $L_{3}$ and residential and industrial lands $L_{9}$ and lands under transportation and communication infrastructure $L_{10}$. The $L_{3}-L_{1}$ relationship earlier revealed for Type II territories was confirmed, but for Krasnodar, the analysis allowed to identify a stronger correlation between perennial plantings and hayfield.

Type IV comprises the territories with the lowest activity of agricultural lands. Climate conditions and soil qualities do not favor farming. The share of agricultural lands in the total land fund is meager compared to Type I-III territories. The scarcity of agricultural lands triggers inter-category competition. In Type IV territories, the strongest correlations were identified between various categories of agricultural lands, specifically, arable land $L_{1}$ and $L_{3}$ and $L_{5}$, as well as hayfields $L_{4}$ and $L_{3}$ and $L_{5}$ (Table 7). Agricultural lands are also affected by barren (in Chukotka, Magadan, and Nenets), woodlands (in Leningrad and Murmansk), wetlands (in Murmansk), and water fund lands (in Yamal-Nenets). 
Table 7. Correlation matrix for Type IV territories

\begin{tabular}{|c|c|c|c|c|c|c|c|c|c|c|c|c|c|}
\hline \multirow{2}{*}{$\mathbf{Y}$} & \multicolumn{13}{|c|}{$\mathbf{X}$} \\
\hline & $\mathbf{R}_{1}$ & $\mathbf{R}_{2}$ & $\mathbf{R}_{3}$ & $\mathbf{R}_{4}$ & $\mathbf{R}_{5}$ & $\mathbf{R}_{6}$ & $\mathbf{R}_{7}$ & $\mathbf{R}_{8}$ & $\mathbf{R}_{9}$ & $\mathbf{R}_{10}$ & $\mathbf{R}_{11}$ & $\mathbf{R}_{12}$ & $\mathbf{R}_{13}$ \\
\hline $\mathrm{R}_{2}$ & 0.110 & & & & & & & & & & & & \\
\hline $\mathrm{R}_{3}$ & 0.984* & 0.270 & & & & & & & & & & & \\
\hline $\mathrm{R}_{4}$ & 0.236 & 0.223 & $0.954 *$ & & & & & & & & & & \\
\hline $\mathrm{R}_{5}$ & $0.900 *$ & 0.121 & 0.275 & $0.943 *$ & & & & & & & & & \\
\hline $\mathrm{R}_{6}$ & $0.701 *$ & 0.269 & $0.604 *$ & 0.275 & 0.265 & & & & & & & & \\
\hline $\mathrm{R}_{7}$ & 0.201 & $0.841^{*}$ & 0.261 & 0.195 & 0.207 & $0.581 *$ & & & & & & & \\
\hline $\mathrm{R}_{8}$ & 0.216 & 0.277 & 0.235 & 0.280 & 0.070 & 0.222 & 0.194 & & & & & & \\
\hline $\mathrm{R}_{9}$ & 0.221 & $0.411 *$ & 0.246 & 0.285 & $0.842 *$ & 0.257 & 0.064 & $0.501 *$ & & & & & \\
\hline $\mathrm{R}_{10}$ & 0.253 & 0.232 & 0.280 & 0.278 & 0.258 & 0.146 & 0.193 & 0.222 & 0.258 & & & & \\
\hline $\mathrm{R}_{11}$ & 0.075 & 0.021 & 0.127 & $0.492 *$ & 0.279 & 0.221 & 0.102 & 0.212 & 0.089 & 0.074 & & & \\
\hline$R_{12}$ & 0.282 & 0.285 & 0.273 & 0.220 & $0.462 *$ & 0.217 & $0.521 *$ & 0.097 & 0.230 & 0.267 & 0.010 & & \\
\hline$R_{13}$ & $0.981 *$ & 0.263 & 0.993* & 0.234 & 0.248 & $0.564 *$ & 0.274 & 0.281 & 0.249 & $0.974 *$ & 0.034 & 0.234 & \\
\hline $\mathrm{R}_{14}$ & 0.934* & 0.162 & $0.864 *$ & 0.187 & $0.840^{*}$ & 0.279 & $0.564 *$ & 0.070 & 0.222 & $0.799 *$ & 0.042 & $0.696^{*}$ & $0.857^{*}$ \\
\hline
\end{tabular}

Note: * strong correlation, $C_{R i}>C_{c v}(0.4255$ for Type IV territories $)$

Source: Authors' development

\section{Discussions}

Following from the results, it seems clear that inter-category relationships within a land fund vary depending on land activity patterns. A share of agricultural land in a land fund is not directly connected with land activity. In the territories, where agricultural land categories dominate in the structure of a land fund, the agricultural land activity could be depressed by non-agricultural lands. In urbanized and densely populated territories, the high activity of agricultural lands is predominantly affected by residential and industrial lands, as well as the lands under transportation and communication. In the industrialized but underpopulated territories, where the agricultural land activity is lower, disturbed lands and barren strongly influence the categories of arable land and perennial plantings. The more moderate agricultural land activity, the stronger inter-category linkages within the fund of agricultural land as a possibility to extend farming patterns at the expense of non-agricultural categories is limited by climatic and geographic factors.

Inter-category relationships within a land fund are commonly studied from a perspective of farming systems, which are defined as an aggregation of individual land-use systems that have broadly similar land resource bases and constraints, and for which similar land distribution patterns would be appropriate (Van de Steeg et al., 2010). Previous studies, for instance, Moll et al. (2007) and Pan et al. (2004), convincingly demonstrated that spatial distribution of farming systems could be affected by various factors operating at both national and regional scales, allocation of arable and other categories of agricultural lands being one of the decisive ones. Echoing Bichler et al. (2005) and Bakker et al. (2011), this study demonstrated that in Russia, spatial 
distribution patterns largely featured natural factors and were mediated by landscape context. The analysis verified that agricultural land was spread unevenly throughout the country and demonstrated regional belt-type concentrations with southern areas being more focused on agricultural production.

Without addressing the spatial distribution of farming systems, it is difficult to explain the aggregate impact of land fund changes at larger out-locus scales. However, a rather clear conclusion that the allocation of land categories within a regional land fund depends on natural factors is challenged by the alternative approaches to the assessment of land fund structure. Actual land distribution patterns may be significantly different from those expected from a knowledge of the natural conditions and shares of individual land categories in a land fund. This finding supplements geographic studies of Hägerstrand (1968) and Rounsevell et al. (2003) who have focused on the exploration of landscape-induced influences (climate, soils, topography) of spatial land distribution on the allocation of agricultural lands. According to Van de Steeg et al. (2010) and Diogo et al. (2015), the spatial distribution of farming systems is determined by not agro-climatic parameters alone, but also population density, degree of urbanization, level of economic and industrial development, and environmental conditions. This study demonstrated that land activity framework was able to adjust the observed allocation of agricultural land as an outcome of socio-economic factors, which is an improvement compared to previous approaches of Tilman et al. (2002), Bichler et al. (2005), and Yerseitova et al. (2018), who tended to explain particular configurations of land categories within a land fund by natural conditions.

In the case of "inactive leaders" (the territories with a high share of arable land in a land fund but low agricultural land activity), many of the differences between spatial-based and activity-based farming systems patterns could indeed be explained by the variations in socio-economic conditions. This well correlates with Van de Steeg et al. (2010) and Gärtner et al. (2013) who empirically confirmed that the functioning of farming systems in agriculture-based economies strongly correlated with such parameters of the external environment as rural development, proximity to economic and market centers, urbanization, and demand for agricultural land from non-agricultural industries. The problem of the emerging conversion of agricultural lands to urban uses is widely recognized. Prishchepov et al. (2013) and Brown et al. (2005) alert to a growing threat of urban development to farming systems and expect the further concentration of arable lands in smaller and more fragmented locuses proximate to urban areas. While in some cases, urban expansion may promote the establishment of farming belts around cities, it nevertheless causes shrinkage of arable land and leads to farming systems fragmentation. Most of the changes in agricultural lands due to urbanization take place on fertile arable soils (Elnaggar, 2013) and irrigated lands (Baker et al., 2014), which brought together make up a considerable amount of agricultural land loss. In return, the increase in agricultural land categories resulted from land reclamation occurs on soils that are lower in their fertility. 
As this study revealed a diversity of more robust and weaker correlations between agricultural lands and various types of urban land categories (residential, industrial, transportation, communication) across Type I-III territories, it should be recognized that inter-category changes in a land fund cannot be simplistically taken as a process of losing agricultural lands to urban development. Instead, there are transitions between agricultural and non-agricultural lands, as well as conversions of agricultural land categories to other uses and vice versa. The authors found that in Type II territories, agricultural lands were more affected by urban development than those in Type I and Type III (an exception is a southern locus in the Type III belt). These results support the findings of Yeh and Huang (2009) and Su et al. (2011) that the proximity to urban development can be a powerful predictor of agricultural landscape changes. With agricultural lands gradually fragmenting and diminishing due to urbanization, many areas in Russia may soon face a reduction in farming opportunities. According to Deng and Li (2016), the expansion of urban and transport infrastructure not only triggers agriculture-to-urban land transfer but also leads to the overexploitation and degradation of remaining agricultural lands. One of the reasons why farming systems are facing higher volatility due to land degradation issues is industrialization. In a situation of spreading degradation of fertile soils due to the increasing industrialization, the overexploitation of the remaining agricultural lands will most likely cause further agricultural land abandonment and fragmentation of arable lands in smaller focals with lower productivity. Nefedova (2013) reports that over $47 \%$ of the total area of Russia (northern and eastern parts of the country) is characterized by a low level of land reclamation and extremely fragmented agricultural land distribution. The Type IV territories, they are remote areas distant from populated places and isolated from large productive agricultural regions. In the Russian North and Far East, low activity of farming lands is coupled with the prevalence of hayfields in the structure of the agricultural land fund.

There have been many approaches to studying inter-category relationships in highfragmented land distribution systems, most deeply investigated being land use, human activities, economic factors, and urban sprawl. Yet, few studies have ever addressed fragmentation as an attribute of land-constrained farming systems from a perspective of land fund structure and land activity. For instance, Qiu et al. (2020) and $\mathrm{Li} \mathrm{(2010)}$ showed that fragmentation might have a significant positive effect on the diversification of farming systems and crop rotation. In the case of low-active agricultural land patterns, however, the high correlation between the categories of arable land, rangelands, hayfields, and perennial plantings rather speaks for inter-category competition for scarce land resources than diversification. This is consistent with the observations of King and Burton (1982) and Tan et al. (2006) that fragmentation results in the decreasing productivity of agricultural lands.

A pressure on arable land from other agricultural categories actualizes an issue of optimization of agricultural land fund structure for agricultural production. Although it is not that relevant in the northern Type IV territories due to the climate and soil conditions, it is critical in low-scale semi-urbanized farming systems (Type I), densely populated Type II territories, and Type III territories in which arable land dominates 
in the structure of a land fund. There have been many models developed to build and assess land fund structure at a regional level with respect to the optimization goal, including RAUMIS, GROWA/WEKU, LUPOlib, and SEAMLESS. However, following Vayssières et al. (2011) and Van de Steeg et al. (2010), the authors' findings show that land-use models should account for a diversity of spatial location factors and different degrees of correlations within categories as well as between agricultural and non-agricultural lands depending on the type of agricultural land activity.

\section{Conclusions}

In this study, the authors attempted to develop an approach for predicting the likely influences of non-agricultural lands on agricultural landscapes, as well as for identifying inter-category relationships between various categories of agricultural land. In the case of diverse agricultural landscapes in Russia, there were identified the interactions between fourteen categories of land within a land fund. Farming systems were mapped based on two approaches: a share of agricultural land categories in a land fund and a rating of "land activity" of agricultural land categories. The sequential employment of the alternative approaches allowed the authors to adjust agriculture and non-agriculture oriented ranking systems to a common basis. It resulted in a finding that the mapping of the farming systems based on the simple contribution of agricultural land to a land fund did not appropriately picture the activity of agricultural land categories. The proposed framework can incorporate complex interactions of a variety of land categories and resulting correlations between them, being therefore suitable for the understanding of land-use patterns, simulation of agricultural land distribution systems, and extrapolation of current trends into the future. The use of readily available land cadaster data makes the approach suitable for a diversity of locations. For the purposes of this study, the authors aggregated internationally-reported classifications determining the allocation of land between agriculture, urban, and nature and Russia's cadaster reports that detail a wider range of agricultural and non-agricultural land categories. Depending on the information available in national cadaster reports, an array of land categories may be easily adjusted. Therefore, the approach proposed in this paper can potentially make a contribution to enable the analysis of land distribution systems in diverse agricultural landscapes at a regional scale internationally. However, the capacity to build reliable models of future transformations of a land fund will depend strongly on a proper understanding of the changes arising from urban, industrial, and socioeconomic development and environmental effects of those processes.

\section{Acknowledgements}

This study was funded by the International and Regional Studies Fund of the Ministry of Education of the People's Republic of China (grant number 19GBQY117).

\section{Conflict of interests}

The authors declare no conflict of interest. 


\section{References}

1. Baker, J.M., Everett, Y., Liegel, L., \& Van Kirk, R. (2014). Patterns of Irrigated Agricultural Land Conversion in a Western U.S. Watershed: Implications for Landscape-Level Water Management and Land-Use Planning. Society \& Natural Resources, 27, 1145-1160. doi: https://doi.org/10.1080/08941920.2014.918231

2. Bakker, M.M., Hatna, E., Kuhlman, T., \& Mücher, C. (2011). Changing Environmental Characteristics of European Cropland. Agricultural Systems, 104(7), 522-532. doi: https://doi.org/10.1016/j.agsy.2011.03.008

3. Benke, K., Wyatt, R., \& Sposito, V. (2011). A Discrete Simulation Approach to Spatial Allocation of Commodity Production for Revenue Optimisation over a Local Region. Journal of Spatial Science, 56(1), 89-101. doi: https://doi.org/10.10 80/14498596.2011.567417

4. Bichler, B., Haering, A.M., \& Dabbert, S. (2005). The Determinants of the Spatial Distribution of Organic Farming in Germany. Berichte Uber Landwirtschaft Hamburg, 83(1), 50-75.

5. Brown, D.G., Johnson, K.M., Loveland, T.R., \& Theobald, D.M. (2005). Rural Land-Use Trends in the Conterminous United States, 1950-2000. Ecological Applications, 15(6), 1851-1863. doi: https://doi.org/10.1890/03-5220

6. Cocklin, C., Smit, B., \& Johnston, T. (1987). Rural Land-Use Analysis and Planning: An Overview. In: C. Cocklin, B. Smit, \& T. Johnston (Eds.), Demands on Rural Lands: Planning for Resource Use (pp. 3-12). New York: Taylor \& Francis.

7. Deng, X., \& Li, Z. (2016). Economics of Land Degradation in China. In: E. Nkonya, A. Mirzabaev, \& J. von Braun (Eds.), Economics of Land Degradation and Improvement - A Global Assessment for Sustainable Development (pp. 385-399). Cham: Springer.

8. Diogo, V. (2018). Agricultural Land Systems: Explaining and Simulating Agricultural Land-Use Patterns. Amsterdam: Vrije Universiteit.

9. Diogo, V., Koomen, E., \& Kuhlman, T. (2015). An Economic Theory-Based Explanatory Model of Agricultural Land-Use Patterns: The Netherlands as a Case Study. Agricultural Systems, 139, 1-16. doi: https://doi.org/10.1016/j. agsy.2015.06.002

10. Elnaggar, A. (2013). Spatial and Temporal Changes in Agricultural Lands Eastern Nile-Delta, Egypt. Journal of Soil Sciences and Agricultural Engineering, 4(3), 187-201. doi: https://doi.org/10.21608/jssae.2013.51151

11. Erokhin, V. (2018). Establishing Food Security and Alternatives to International Trade in Emerging Economies. Hershey: IGI Global.

12. Erokhin, V., Gao, T., \& Ivolga, A. (2020). Structural Variations in the Composition of Land Funds at Regional Scales across Russia. Land, 9(6), 201. doi: https://doi. org/10.3390/land9060201 
13. Federal Service for State Registration, Cadastre and Cartography. (2020). Availability and Allocation of Lands in the Russian Federation. Retrieved from https://rosreestr. ru/site/activity/sostoyame-zemerrossii/gosudarstvennyy-natsionalnyy-doklad-osostoyanii-i-ispolzovanii-zemel-v-rossiyskoy-federatsii/ (June 26, 2020).

14. Federal State Statistics Service. All-Russian Agricultural Census 2016, Retrieved from https://www.gks.ru/519 (June 25, 2020).

15. Federal State Statistics Service. Regions of Russia, Social and Economic Indicators, Retrieved from https://www.gks.ru/folder/210/document/13204 (June 25, 2020).

16. Gärtner, D., Keller, A., \& Schulin, R. (2013). A Simple Regional Downscaling Approach for Spatial Distributing Land Use Types for Agricultural Land. Agricultural Systems, 120, 10-19. doi: https://doi.org/10.1016/j.agsy.2013.04.006

17. Hägerstrand, T. (1968). Innovation Diffusion as a Spatial Process. Chicago: University of Chicago Press.

18. Irwin, E.G., \& Geoghegan, J. (2001). Theory, Data, Methods: Developing Spatially Explicit Economic Models of Land Use Change. Agriculture, Ecosystems and Environment, 85(1), 7-23. doi: https://doi.org/10.1016/S0167-8809(01)00200-6

19. King, R., \& Burton, S. (1982). Land Fragmentation: Notes on a Fundamental Rural Spatial Problem. Progress in Human Geography, 6(4), 475-494. doi: https:/doi. org/10.1177/030913258200600401

20. Koomen, E., Diogo, V., Dekkers, J., \& Rietveld, P. (2015). A Utility-Based Suitability Framework for Integrated Local-Scale Land-Use Modelling. Computers, Environment and Urban Systems, 50, 1-14. doi: https://doi.org/10.1016/j. compenvurbsys.2014.10.002

21. Li, Y. (2010). Land Fragmentation's Larger-Scale Farming and the Input-Output Efficiency of Rice Planter. Journal of South China Agricultural University, 10, 72-78.

22. Margules, C.R., \& Pressey, R.L. (2000). Systematic Conservation Planning. Nature, 405, 243-253. doi: https://doi.org/10.1038/35012251

23. Moll, H.A.J., Staal, S.J., \& Ibrahim, M.N.M. (2007). Smallholder Dairy Production and Markets: A Comparison of Production Systems in Zambia, Kenya and Sri Lanka. Agricultural Systems, 94(2), 593-603. doi: https://doi.org/10.1016/j. agsy.2007.02.005

24. Moss, M. (1985). Land Processes and Land Classification. Journal of Environmental Management, 20, 295-319.

25. Nefedova, T. (2013). Ten Topical Issues about Rural Russia: A Geographer's Viewpoint. Moscow: LENAND.

26. Novkovic, N., Somodji, S., \& Matkovic, M. (2010). Selection of Agricultural Land for Multifunctional Agriculture. Applied Studies in Agribusiness and CommerceAPSTRACT, 4(1-2), 49-52. doi: https://doi.org/10.19041/APSTRACT/2010/1-2/6 
27. Omar, H., Joarder, A., \& Riaz, M. (2015). On a Correlated Variance Ratio Distribution and Its Industrial Application. Communication in Statistics - Theory and Methods, 44(2), 261-274. doi: https://doi.org/10.1080/03610926.2012.735324

28. Pan, W.K.Y., Walsh, S.J., Bilsborrow, R.E., Frizzelle, B.G., Erlien, C.M., \& Baquero, F. (2004). Farm-Level Models of Spatial Patterns of Land Use and Land Cover Dynamics in the Ecuadorian Amazon. Agriculture, Ecosystems and Environment, 101(2-3), 117-134. doi: https://doi.org/10.1016/j.agee.2003.09.022

29. Prishchepov, A., Müller, D., Dubinin, M., Baumann, M., \& Radeloff, V. (2013). Determinants of Agricultural Land Abandonment in Post-Soviet European Russia. Land Use Policy, 30(1), 873-884. doi: https://doi.org/10.1016/j. landusepol.2012.06.011

30. Qiu, L., Zhu, J., Pan, Y., Wu, S., Dang, Y., Xu, B., \& Yang, H. (2020). The Positive Impacts of Landscape Fragmentation on the Diversification of Agricultural Production in Zhejiang Province, China. Journal of Cleaner Production, 251. doi: https://doi.org/10.1016/j.jclepro.2019.119722

31. Rounsevell, M.D.A., Annetts, J.E., Audsley, E., Mayr, T., \& Reginster, I. (2003). Modelling the Spatial Distribution of Agricultural Land Use at the Regional Level. Agriculture, Ecosystems and Environment, 95(2-3), 465-479. doi: https://doi. org/10.1016/S0167-8809(02)00217-7

32. Sangngam, P. (2014). Ratio Estimators Using Coefficient of Variation and Coefficient of Correlation. Modern Applied Science, 8(5), 70-79. doi: https:/doi. org/10.5539/mas.v8n5p70

33. Stacherzak, A., Heldak, M., Hajek, L., \& Przybyla, K. (2019). State Interventionism in Agricultural Land Turnover in Poland. Sustainability, 11(6), 15-34. doi: https:// doi.org/10.3390/su11061534

34. Su, S., Jiang, Z., Zhang, Q., \& Zhang, Y. (2011). Transformation of Agricultural Landscapes under Rapid Urbanization: A Threat to Sustainability in Hang-Jia-Hu Region, China. Applied Geography, 31(2), 439-449. doi: https://doi.org/10.1016/j. apgeog.2010.10.008

35. Tan, S., Heerink, N., \& Qu, F. (2006). Land Fragmentation and Its Driving Forces in China. Land Use Policy, 23(3), 272-285. doi: https://doi.org/10.1016/j. landusepol.2004.12.001

36. Tilman, D., Cassman, K., Matson, P., Naylor, R., \& Polasky, S. (2002). Agricultural Sustainability and Intensive Production Practices. Nature, 418, 671-677.

37. Van de Steeg, J.A., Verburg, P.H., Baltenweck, I., \& Staal, S.J. (2010). Characterization of the Spatial Distribution of Farming Systems in the Kenyan Highlands. Applied Geography, 30(2), 239-253. doi: https://doi.org/10.1016/j. apgeog.2009.05.005 
38. Vayssières, J., Vigne, M., Alary, V., \& Lecomte, P. (2011). Integrated Participatory Modelling of Actual Farms to Support Policy Making on Sustainable Intensification. Agricultural Systems, 104(2), 146-161. doi: https://doi.org/10.1016/j. agsy.2010.05.008

39. Verburg, P.H., Erb., K.H., Mertz, O., \& Espindola, G. (2013). Land System Science: Between Global Challenges and Local Realities. Current Opinions on Environment and Sustainability, 5(5), 433-437. doi: https://doi.org/10.1016/j.cosust.2013.08.001

40. Werts, C., Rock, D., Linn, R., \& Joreskog, K. (1976). Comparison of Correlations, Variances, Covariances, and Regression Weights with or without Measurement Error. Psychological Bulletin, 83(6), 1007-1013. doi: https://doi.org/10.1037/00332909.83.6.1007

41. Yeh, C.T., \& Huang, S.L. (2009). Investigating Spatiotemporal Patterns of Landscape Diversity in Response to Urbanization. Landscape and Urban Planning, 93(3-4), 151-162. doi: https://doi.org/10.1016/j.landurbplan.2009.07.002

42. Yerseitova, A., Issakova, S., Jakisheva, L., Nauryzbekova, A., \& Moldasheva, A. (2018). Efficiency of Using Agricultural Land in Kazakhstan. Entrepreneurship and Sustainability Issues, 6(2), 558-576. doi: https://doi.org/10.9770/jesi.2018.6.2(7) 